\title{
Pengaruh Resiliensi Matematis terhadap Kemampuan Komunikasi
} Matematis

\author{
Endang Suparni ${ }^{1 *}$, Maya Nurfitriyanti ${ }^{2}$, \& Lin Mas Eva ${ }^{3}$ \\ 1, 2, 3 Universitas Indraprasta PGRI, Jakarta, Indonesia
}

\section{INFO ARTICLES}

Article History:

Received: 03-03-2021

Revised: 06-05-2021

Approved: 07-06-2021

Publish Online: 30-06-2021

Key Words:

The Mathematical Resilience; Mathematical Communication;

CC (†) (O) This article
is licensed under a Creative Commons
Attribution-ShareAlike 4.0 International
License.

Correspondence Address: Jln. Raya Tengah Gedong, Pasar Rebo, Jakarta Timur, 13910, Indonesia; e-mail: ndank.sekar@gmail.com

How to Cite (APA $6^{\text {th }}$ Style): Suparni, E., Nurfitriyanti, M., \& Eva, L.M. (2021). Pengaruh Resiliensi Matematis terhadap Kemampuan Komunikasi Matematis. JKPM (Jurnal Kajian Pendidikan Matematika), 6(2): 157-166.

Copyright: 2021 Endang Suparni, Maya Nurfitriyanti, Lin Mas Eva

Competing Interests Disclosures: The authors declare that they have no significant competing financial, professional or personal interests that might have influenced the performance or presentation of the work described in this manuscript. 


\section{PENDAHULUAN}

Pendidikan merupakan investasi penting dalam menghadapi masa depan dunia secara global. Dimana di era revolusi industri 4.0, sistem pendidikan harus terus diperbarui agar dapat mengikuti perkembangan zaman. Kini Indonesia telah memasuki era revolusi industri 4.0, ditandai dengan penggunaan mesin-mesin automasi yang terintegrasi jaringan internet (internet of things). Banyak hal yang tak terpikirkan sebelumnya, tiba-tiba muncul dan menjadi inovasi baru, serta membuka lahan bisnis yang sangat besar. Contoh terdekatnya munculnya transportasi dengan sistem ride-sharing seperti ojek online. Tren ini mengubah banyak bidang kehidupan manusia, termasuk ekonomi, dunia kerja, bahkan gaya hidup. Singkatnya, revolusi industri 4.0 menanamkan teknologi cerdas yang dapat terhubung dengan berbagai bidang kehidupan manusia.

Dalam dunia pendidikan, matematika dipandang sebagai dasar bagi pengembangan ilmu dan teknologi, matematika memiliki sebuah kekuatan yang mampu diaplikasikan ke dalam beberapa aspek, termasuk teknologi. Sejak awal perkembangannya, matematika menjadi tenaga pendukung bagi perkembangan teknologi. Berkembangnya teknologi informasi dan komunikasi sekarang ini tidak terlepas dari adanya campur tangan matematika. Sebagai contoh adalah penggunaan logika matematika sebagai dasar bahasa pemrograman, struktur data, sistem digital, basis data, dan lainnya yang mempergunakan logika secara intensif. Melalui belajar matematika dapat dibentuk pola berpikir logika, abstraksi, serta penalaran deduktif, sehingga matematika sebagai salah satu mata pelajaran yang harus dipelajari pada setiap jenjang pendidikan formal.

Namun kenyataannya pembelajaran matematika di Indonesia masih belum memberikan hasil yang memuaskan. Hal ini dibuktikan dengan adanya hasil Programme for International Student Assessment (PISA) untuk Indonesia tahun 2018, telah diumumkan The Organisation for Economic Cooperation and Development (OECD), hasilnya menunjukan tren naik turun dalam pencapaian kemampuan matematika. Tahun 2003, capaian skor PISA matematika di angka 360, naik menjadi angka 391 di tahun 2006, mengalami penurunan di tahun 2009 diangka 371, naik menjadi skor 375 di tahun 2012, di tahun 2015 mengalami kenaikan diangka 386, sedangkan di tahun 2018 skor PISA matematika Indonesia kembali turun diangka 379. Sedangkan rata-rata skor PISA negara anggota OECD untuk matematika dan sains 489, China dan Singapura menempati peringkat tertinggi untuk skor matematika dengan skor 591 dan 569. Berdasarkan hasil PISA diperoleh gambaran masih ditemukannya tingginya disparitas mutu dan hasil pendidikan tiap daerah. Terutama sekolah di daerah yang letaknya jauh dari perkotaan, dilansir via kompas (04 Desember 2019).

Shindy \& Nurfitriyanti (2020) menyatakan saat ini pembelajaran matematika dianggap pelajaran yang paling menakutkan bagi peserta didik. Ilmunya yang bersifat abstrak, menjadi salah satu alasan mengapa pelajaran ini selalu dihindari. Terkadang guru juga mengalami kesulitan membangun komunikasi secara dua arah dalam pembelajaran mengingat masih terbatasnya media untuk memvisualisasikan matematika secara konkret kepada peserta didik. Pendapat tersebut diperkuat oleh Hasbullah \& Yogi (2015) menyatakan bahwa karakteristik matematika yang membedakannya dengan pelajaran yang lain yaitu: memiliki objek kajian yang abstrak, pembahasannya mengandalkan nalar, pengertian atau konsep bersifat sangat jelas dan terjaga konsistensinya, melibatkan perhitungan atau operasi, dan dapat dialih gunakan dalam berbagai aspek keilmuan maupun kehidupan sehari-sehari. Melalui pengajaran matematika disekolah yang mengembangkan kemampuan komunikasi matematis, peserta didik diajak berlatih untuk mengkomunikasikan ide atau gagasan dengan simbol, tabel, diagram, atau media lain untuk memperjelas keadaan atau masalah matematika.

Dalam National Council of Teachers of Mathematics NCTM (2000) disebutkan bahwa "communication is an essential part of mathematics and mathematic education" yang artinya adalah komunikasi sebagai salah satu bagian esensial dalam matematika dan pendidikan matematika. Melalui komunikasi dapat menciptakan suatu pemahaman dan pengetahuan yang mereka peroleh dalam pembelajaran. Menurut Kurnia, dkk (2018) kemampuan komunikasi matematis adalah kemampuan yang sangat penting dan perlu dimiliki oleh peserta didik dan salah satunya yaitu kemampuan 
mengomunikasikan gagasan/ide dengan diagram, simbol, dan tabel dalam menyelesaikan masalah matematika. Adapun untuk menilai kemampuan peserta didik yang berkaitan dengan komunikasi matematis diperlukan indikator-indikator kemampuan komunikasi matematis.

Indikator kemampuan komunikasi matematis yang dikemukakan oleh Sumarmo dalam (Husna, \& Fatimah, 2013) sebagai berikut: (1) Menyatakan suatu situasi, gambar, diagram, atau benda nyata ke dalam bahasa, simbol, idea, atau model matematika; (2) Menjelaskan idea, situasi, dan relasi matematika secara lisan atau tulisan dengan benda nyata, gambar, grafik atau bentuk aljabar; (3) Menyatakan peristiwa sehari-hari dalam bahasa atau simbol matematika; (4) Mendengarkan, berdiskusi, dan menulis tentang matematika; (5) Membaca dengan pemahaman suatu representasi matematika tertulis dan menyusun pertanyaan yang relevan; (6) Membuat konjektur, menyusun argumen, dan merumuskan definisi dan generalisasi. Tanpa komunikasi yang baik, maka perkembangan matematika akan terhambat. Karena matematika merupakan pelajaran yang terdiri dari bahasa simbol, bersifat abstrak, memerlukan analisis dan perhitungan menjadi alasan betapa pentingnya peserta didik untuk mengembangkan kemampuan komunikasi matematis

Namun kenyataanya proses pembelajaran matematika di lapangan masih sering kali menemui permasalahan. Permasalahan kemampuan komunikasi matematis di SMP Insan Nur Muhammad Bogor, adalah rendahnya tingkat kemampuan peserta didik dalam memahami dan menyatakan situasi ke dalam bahasa matematika. Hal tersebut terlihat dari ketuntasan belajar peserta didik di kelas IX pada materi bangun ruang di tahun ajaran 2019/2020 adalah 43\%, peserta didik mengalami ketuntasan. Artinya nilai sudah memenuhi kriteria ketuntasan minimal (KKM) yaitu nilai 70 dan sisanya 57\% adalah peserta didik yang tidak tuntas. Ketidaktuntasan tersebut dikarenakan peserta didik mengalami kesulitan ketika diberikan soal yang disajikan dalam bentuk diagram, tabel, dan gambar. Selain itu sering melakukan kesalahan saat menyatakan permasalahan pada soal ke dalam notasi dan simbol matematika Dengan kondisi tersebut, dapat dikatakan bahwa kemampuan komunikasi matematis peserta didik perlu ditindak lanjuti. Untuk meningkatkan kemampuan komunikasi ada beberapa aspek yang mempengaruhi salah satunya adalah kemampuan yang memperlihatkan sikap tidak mudah menyerah dan memperkuat diri dalam situasi sulit, adaptif, kemampuan tersebut dikatakan sebagai resiliensi. Resiliensi terhadap matematika sering disebut resiliensi matematis.

Dweck (dalam Hendriana, Rochaeti, \& Sumarmo, 2017) mengemukakan resiliensi matematis memuat sikap tekun atau gigih dalam menghadapi kesulitan, bekerja atau belajar kolaboratif dengan teman sebaya, memiliki keterampilan berbahasa untuk menyatakan pemahaman matematis dan menguasai teori belajar matematis. Gigih dalam menghadapi kesulitan artinya peserta didik memperkuat diri dalam situasi yang sulit, bangkit dari keterpurukan atau situasi yang tidak menyenangkan. JohnstonWilder, \& Lee, (2010) mengemukakan bahwa resiliensi matematis memiliki empat faktor yaitu: a) Percaya pada kemampuan otak dapat ditumbuhkan; b) Pemahaman personal terhadap nilai-nilai matematika; c) Pemahaman bagaimana cara bekerja dalam matematika; d) Kesadaran akan dukungan teman sebaya, orang dewasa lainya, ICT, internet, dan lain sebagainya. Apabila ke empat faktor tersebut tertanam didalam diri peserta didik akan menjadikan mereka memiliki resiliensi matematis yang kuat, mendukung tumbuhnya sikap tekun dan gigih menghadapi kesulitan atau hambatan belajar matematika. Sebaliknya, peserta didik dengan resiliensi matematis yang rendah akan kehilangan sikap tekun dan gigih dan mudah menyerah ketika menghadapi kesulitan.

Mengetahui tingkat resiliensi matematis peserta didik, apakah masuk dalam kategori tinggi, sedang, dan rendah maka dibutuhkan indikator resiliensi matematis. Indikator tersebut mengacu pada Sumarmo dalam (Hendriana, Rochaeti, \& Sumarmo, 2017) merangkumkan sebagai berikut: (1) Menunjukkan sikap tekun, yakin atau percaya diri, bekerja keras, tidak mudah menyerah menghadapi masalah, kegagalan, dan ketidakpastian; (2) Menunjukkan keinginan bersosialisasi, mudah memberi bantuan, berdiskusi dengan sebayanya, dan beradaptasi dengan lingkungannya; (3) Memunculkan ide atau cara baru dan mencari solusi kreatif terhadap tantangan; (4) Menggunakan pengalaman kegagalan untuk membangun motivasi diri; (5) Menunjukkan rasa ingin tahu, merefleksi, meneliti, dan 
memanfaatkan beragam sumber; (6) Memiliki kemampuan berbahasa, mengontrol diri dan sadar akan perasaannya.

Resiliensi matematis memiliki andil dalam mempengaruhi kemampuan komunikasi matematis yang tercermin dari hasil belajar matematika peserta didik, hal ini diperkuat oleh penelitian yang dilakukan oleh Iman \& Firmansyah (2020), yang berjudul "Pengaruh Kemampuan Resiliensi Matematis Terhadap Hasil Belajar Matematika". Hasil penelitian menunjukan bahwa terdapat pengaruh kemampuan resiliensi matematis terhadap hasil belajar matematika. Pengaruhnya sebesar 22,3\%, artinya kemampuan resiliensi matematis juga ikut memegang andil dalam mempengaruhi hasil belajar matematika peserta didik. Di mana apabila kemampuan resiliensi matematis peserta didik tinggi maka hasil belajar peserta didik tersebut juga akan tinggi.

Menyadari pentingnya resiliensi matematis bagi peserta didik, diperlukan upaya untuk meningkatkannya. Dengan tujuan memfasilitasi pengembangan kemampuan komunikasi peserta didik. Karena dengan memiliki resiliensi matematis, peserta didik dapat mengendalikan dirinya, untuk pantang menyerah dalam menyelesaikan masalah yang membutuhkan kemampuan komunikasi matematis.

\section{METODE}

Penelitian ini dilaksanakan di SMP Insan Nur Muhammad Bogor pada peserta didik kelas IX tahun ajaran 2019/2020 semester ganjil. Metode penelitian yang digunakan dalam penelitian ini adalah metode survei korelasional. Pada penelitian ini terdiri dari 1 variabel bebas, yakni resiliensi matematis dan variabel terikat yaitu kemampuan komunikasi matematis. Pada penelitian ini, dilakukan 3 tahap perhitungan statistik, antara lain uji deskriptif data, uji persyaratan analisis data dan uji hipotesis. Uji deskriptif data yaitu untuk mengetahui nilai mean, median, modus, simpangan baku, dan varians dari tiap-tiap variabel. Uji persyaratan analisis data yaitu uji normalitas dan uji linearitas. Uji hipotesis menggunakan teknik uji regresi sederhana. Adapun desain penelitian disajikan dalam Gambar 1.

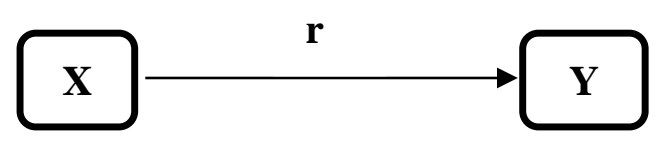

\section{Gambar 1. Desain Penelitian}

Keterangan:

Y : Kemampuan Komunikasi Matematis

$\mathrm{X} \quad$ : Resiliensi Matematis

$\mathrm{r} \quad$ : Pengaruh Resiliensi Matematis (X) terhadap Kemampuan Komunikasi Matematis (Y)

Sampel yang digunakan dalam penelitian ini sebanyak 35 peserta didik. Pengambilan sampel dilakukan dengan menggunakan teknik Purposive Sampling. Menurut Sugiyono (2017) teknik Purposive Sampling yaitu teknik penentuan sampel dengan pertimbangan tertentu. Pada penelitian ini sampel yang dipilih berdasarkan pertimbangan dari guru mata pelajaran matematika. Dalam menentukan besar sampel peneliti menggunakan pendapat yang dipaparkan oleh Arikunto (2010) jika subjeknya kurang dari 100 orang sebaiknya diambil semuanya, jika subjeknya besar atau lebih dari 100 orang dapat diambil $10-15 \%$ atau $20-25 \%$ atau lebih. Karena banyaknya subjek yang diteliti lebih dari 100 orang, yaitu 108 peserta didik maka peneliti mengambil sampel sebanyak $32 \%$ dari populasi sebanyak 108 orang yaitu 35 peserta didik. Instrumen yang digunakan adalah berupa angket untuk variabel resiliensi matematis, dan soal tes essay untuk variabel kemampuan komunikasi matematis.

Sebelum pengambilan data, instrumen setiap variabel diuji validasi dan reliabilitas terlebih dahulu. Untuk pengujian validasi menggunakan rumus $r_{x y}$ sedangkan reliabilitas menggunakan rumus Alpha Cronbach. Jumlah instrumen valid untuk kemampuan komunikasi matematis sebanyak 9 butir 
soal dengan nilai reliabilitas 0,81 . Untuk jumlah instrumen valid pada variabel resiliensi matematis sebanyak 23 soal dengan nilai reliabilitas sebesar 0,88 .

\section{HASIL}

Deskriptif data penelitian dilakukan untuk menggambarkan variabel resiliensi matematis dan variabel kemampuan komunikasi matematis peserta didik di SMP Insan Nur Muhammad Bogor. Analisis deskriptif terdiri dari mean, median, modus, varians dan standar deviasi. Selanjutnya hasil analisis tersebut dapat digunakan untuk menjawab rumusan masalah penelitian. Secara deskriptif, data hasil penelitian dapat dinyatakan dalam Tabel 1.

Tabel 1. Analisis Deskripsi Data

\begin{tabular}{ccc}
\hline Statistik & Resiliensi Matematis & Kemampuan Komunikasi Matematis \\
\hline Nilai Tertinggi & 82 & 73 \\
Nilai Terendah & 61 & 45 \\
Mean & 70,61 & 59,14 \\
Median & 69,36 & 58,67 \\
Modus & 67 & 56,50 \\
Varians & 31,52 & 50,42 \\
Standar Deviasi & 5,61 & 7,10 \\
\hline
\end{tabular}

Sumber: diolah dari data penelitian, 2020.

Berdasarkan Tabel 1. dapat dikatakan bahwa resiliensi matematis dan komunikasi matematis peserta didik tergolong kurang baik. Hal ini disebabkan karena nilai mean dari kedua variabel tersebut lebih tinggi dari nilai modus

Sebelum melakukan pengujian hipotesis dengan uji-F, maka diperlukan pengujian persyaratan analisis data, yang dilakukan yaitu uji normalitas dan Linieritas. Uji normalitas yang digunakan adalah uji Chi-Kuadrat, uji ini digunakan untuk mengetahui apakah data yang diperoleh pada penelitian berdistribusi normal atau tidak. Menurut Supardi (2013), kriteria pengujian data terima $\mathrm{H}_{0}$ jika $\chi^{2}$ hitung $<\chi_{\text {tabel }}^{2}$ berdistribusi normal dan tolak $\mathrm{H}_{0}$ jika $\chi^{2}{ }_{\text {hitung }}>\chi_{\text {tabel }}^{2}$ tidak berdistribusi normal. Untuk $\chi_{\text {tabel }}^{2}$ diperoleh dari tabel Chi-Kuadrat untuk taraf signifikansi $\alpha=0,05$ dan $d k=k-1=$ 6- $1=5$ didapat nilai $\chi_{\text {tabel }}^{2}=11,070$. Perhitungan hasilnya dapat dilihat pada Tabel 2.

Tabel 2. Ringkasan Hasil Uji Normalitas

\begin{tabular}{ccccc}
\hline Kelas & $\begin{array}{c}\text { Jumlah } \\
\text { Sampel }\end{array}$ & $\chi^{2}$ hitung & $\begin{array}{c}\chi^{2} \text { tabel } \\
\boldsymbol{\alpha}=\mathbf{0 , 0 5}\end{array}$ & Keterangan \\
\hline $\begin{array}{c}\text { Resiliensi Matematis } \\
\text { Kemampuan Komunikasi }\end{array}$ & 35 & 8,921 & 11,070 & Hoditerima, maka data $_{0}$ berdistribusi normal \\
Matematis & 35 & 2,517 & 11,070 & .
\end{tabular}

Sumber: diolah dari data penelitian, 2020.

Berdasarkan perhitungan yang ditampilkan pada Tabel 2. diketahui bahwa untuk kemampuan komunikasi matematis diperoleh $\chi^{2}$ hitung $=2,517$, sedangkan nilai $\chi_{\text {tabel }}^{2}=11,070$. Karena $\chi_{\text {hitung }}^{2}<\chi_{\text {tabel }}^{2}$ yaitu $2,517<11,070$. Maka $\mathrm{H}_{0}$ diterima, sehingga dapat disimpulkan bahwa data kemampuan komunikasi matematis $(Y)$ berdistribusi normal. Untuk data resiliensi matematis diperoleh $\chi^{2}$ hitung adalah 8,921 dan $\chi_{\text {tabel }}^{2}=11,070$, diperoleh $\chi^{2}$ hitung $<\chi_{\text {tabel }}^{2}$ yaitu 8,921 <11,070. Maka $\mathrm{H}_{0}$ diterima, sehingga dapat disimpulkan bahwa data resiliensi matematis $(\mathrm{X})$ berdistribusi normal.

Selanjutnya setelah uji normalitas maka dilakukan uji persyaratan data yang kedua yaitu uji linieritas dimana uji ini untuk mengetahui apakah data berpola linier atau tidak. Kriteria pengujiannya adalah terima Ho jika $F_{\text {hitung }}<F_{\text {tabel }}$ dan Ho ditolak jika $F_{\text {hitung }}>F_{\text {tabel. }}$. Untuk $F_{\text {tabel }}$ diperoleh dari table 
distribusi $\mathrm{F}$ dengan taraf signifikansi $\alpha=0,05, \mathrm{dk}_{1}=\mathrm{dk}_{\mathrm{TC}}=16$ dan $\mathrm{dk}_{2}=\mathrm{dk}_{\mathrm{err}}=17$. Maka diperoleh nilai $\mathrm{F}_{\text {tabel }}=2$ 2,29. Perhitungan hasilnya dapat dilihat pada Tabel 3.

Tabel 3. Tabel Ringkasan Anava Variabel X dan Y untuk Uji Linieritas

\begin{tabular}{|c|c|c|c|c|c|}
\hline $\begin{array}{c}\text { Sumber } \\
\text { Varians (SV) }\end{array}$ & Dk & $\mathrm{JK}$ & RJK & $F_{\text {hitung }}$ & $F_{\text {tabel }}$ \\
\hline Total & 35 & 122717 & - & & \\
\hline Regresi (a) & 1 & 121128,0 & 121128,03 & & \\
\hline Regresi (b|a) & 1 & 189,88 & 189,88 & 1,78 & 2,29 \\
\hline Residu & 33 & 1399,09 & 42,38 & & \\
\hline Tuna Cocok & 16 & 876,76 & 54,80 & & \\
\hline Kesalahan (error) & 17 & 522,33 & 30,73 & & \\
\hline
\end{tabular}

Sumber: diolah dari data penelitian, 2020.

Berdasarkan perhitungan yang ditampilkan pada Tabel 3. diketahui bahwa $F_{\text {hitung }}<\mathrm{F}_{\text {tabel }}$, yaitu $1,78<2,29$, maka $\mathrm{H}_{0}$ diterima, sehingga regresi berpola linear.

Pengujian hipotesis penelitian terdiri dari uji korelasi dan uji regresi sederhana. Perhitungan korelasi sederhana digunakan untuk mengukur kekuatan hubungan antar variabel. Kriteria pengujiannya adalah terima $\mathrm{H}_{0}$ jika $t_{\text {hitung }} \leq \mathrm{t}_{\text {tabel }}$ dan $\mathrm{H}_{0}$ ditolak jika $\mathrm{t}_{\text {hitung }}>\mathrm{t}_{\text {tabel }}$, lebih lanjut dapat dilihat pada Tabel 4.

Tabel 4. Korelasi Antara Resiliensi Matematis dan Komunikasi Matematis

\begin{tabular}{cccc}
$\mathrm{R}$ & $\mathrm{R}$ Square & $\mathrm{t}_{\text {hitung }}$ & $\mathrm{t}_{\text {tabel }}$ \\
\hline 0,3463 & 0,1199 & 2,12 & 1,684 \\
\hline
\end{tabular}

Sumber: diolah dari data penelitian, 2020.

Dari tabel distribusi $\mathrm{t}$, untuk taraf signifikansi $\mathrm{a}=0,05$ dan $d k=n-2=35-2=$ 33 , diperoleh $t_{\text {tabel }}=1,684$. Karena $t_{\text {hitung }}$ lebih besar dari $t_{\text {tabel }}(2,120>1,684)$, maka $\mathrm{H}_{0}$ ditolak sehingga disimpulkan terdapat korelasi positif yang signifikan antara resiliensi matematis (X) dengan kemampuan komunikasi matematis (Y). Untuk menghitung seberapa besar kontribusi resiliensi matematis terhadap kemampuan komunikasi matematis dapat dinyatakan dengan koefisien determinasi (KD) dengan perhitungan sebagai berikut:

$$
\begin{aligned}
\mathrm{KD} & =(\mathrm{r})^{2} \times 100 \% \\
& =(0,346)^{2} \times 100 \% \\
& =0,1199 \times 100 \% \\
& =11,99 \%
\end{aligned}
$$

Diperoleh nilai koefisien determinasi sebesar 11,99\%, hal ini berarti kontribusi resiliensi matematis terhadap kemampuan komunikasi matematis sebesar $11,99 \%$, sedangkan sisanya sebesar 88,01 ditentukan oleh faktor lain.

Selain korelasi sederhana, pengujian hipotesis menggunakan uji regresi sederhana. Perhitungan pola regresi sebagai berikut:

$$
\begin{aligned}
a & =\frac{\sum Y \sum X^{2}-\sum X \cdot \sum X Y}{n \cdot \sum X^{2}-\left(\sum X\right)^{2}} \\
& =\frac{2059.175102-2468.145641}{35.175102-2468^{2}} \\
& =29,22
\end{aligned}
$$




$$
\begin{aligned}
b & =\frac{n \sum X Y-\sum X \cdot \sum Y}{n \cdot \sum X^{2}-\left(\sum X\right)^{2}} \\
& =\frac{35 \times 145641-(2468)(2059)}{35 \times 175102-2468^{2}} \\
& =0,42
\end{aligned}
$$

Kriteria pengujian untuk pengujian hipotesis regresi linier sederhana adalah terima $\mathrm{H}_{0}$ jika $\mathrm{F}_{\text {hitung }}$ $<\mathrm{F}_{\text {tabel }}$ dan $\mathrm{H}_{0}$ ditolak jika $\mathrm{F}_{\text {hitung }}>\mathrm{F}_{\text {tabel. }}$ Untuk $\mathrm{F}_{\text {tabel }}$ ditentukan dari tabel distribusi $\mathrm{F}$, dengan taraf signifikansi $\alpha=0,05$ serta $\mathrm{dk}$ pembilang, $\mathrm{k}=1$ ( $\mathrm{k}=$ banyaknya variabel bebas) dan dk penyebut, $n-$ $2=35-2=33$ adalah 4,13. Perhitungan hasil pola regresi disajikan dalam Tabel 5.

Tabel 5. Ringkasan ANAVA Regresi Linier Sederhana

\begin{tabular}{cccccc}
\hline $\begin{array}{c}\text { Sumber } \\
\text { Varians (SV) }\end{array}$ & Dk & JK & RJK & $F_{\text {hitung }}$ & $F_{\text {tabel }}$ \\
\hline Total & 35 & 122717 & - & & \\
Regresi (a) & 1 & 121128,03 & 121128,03 & & \\
Regresi (b|a) & 1 & 189,88 & 189,88 & 4,48 & 4,13 \\
Residu & 33 & 1399,09 & 42,38 & & \\
\hline
\end{tabular}

Sumber: diolah dari data penelitian, 2020.

Model hipotesis penelitian ini didapat persamaan regresi sederhana $\hat{Y}=29,22+$ $0,42 x$. Artinya variabel bebas tersebut memiliki nilai konstanta sebesar 29,22 dengan angka arah 0,42. Karena nilai b (angka arah) positif maka arah regresinya naik. Hasil pengujian pengujian koefisien regresi sederhana diperoleh $\mathrm{F}_{\text {hitung }}>\mathrm{F}_{\text {tabel, }}$, yaitu 4,48 > 4,13 maka $\mathrm{H}_{0}$ ditolak sehingga disimpulkan terdapat pengaruh yang signifikan antara resiliensi matematis $(\mathrm{X})$ terhadap kemampuan komunikasi matematis (Y).

\section{PEMBAHASAN}

Berdasarkan hasil penelitian, dapat ditarik kesimpulan bahwa terdapat pengaruh yang signifikan antara resiliensi matematis terhadap kemampuan komunikasi matematis, pada peserta didik kelas IX SMP Insan Nur Muhammad Bogor tahun ajaran 2019/2020. Kesimpulan ini didasarkan pada hasil perhitungan signifikansi regresi sederhana dengan nilai $\mathrm{F}_{\text {hitung }}$ sebesar 4,48 dan harga $\mathrm{F}_{\text {tabel }}$ sebesar 4,13. Pola regresi yang terbentuk yaitu $\hat{Y}=29,22+0,42 x$. Artinya variabel bebas tersebut memiliki nilai konstanta sebesar 29,22 dengan angka arah 0,42. Karena nilai b (angka arah) positif maka arah regresinya naik. Selanjutnya, nilai koefisien determinasi menunjukkan bahwa resiliensi matematis turut andil dalam mempengaruhi kemampuan kemampuan komunikasi matematis peserta didik. Hal ini ditunjukan dari nilai koefisien korelasi $r_{x y}$ sebesar 0,3463 yang berarti Sumbangan variabel resiliensi matematis terhadap kemampuan komunikasi matematis sebesar $11,99 \%$, sedangkan $88,01 \%$ ditentukan oleh variabel-variabel lain dan faktor lain yang tidak dijelaskan dalam penelitian ini.

Lingkungan sosial menjadi faktor kuat yang mendukung keberhasilan proses belajar disekolah. Faktor lingkungan sosial disekolah terdiri dari dukungan sosial serta keterlibatan individu dalam lingkungan sosialnya. Efek menguntungkan dari dukungan sosial muncul baik melalui interaksi individu dengan teman dekat atau representasi sosial psikologis individu. Hal ini sejalan dengan pendapat Sarafino \& Smith (2011) dukungan yang sesuai akan sangat membantu individu untuk memenuhi kebutuhan saat mengalami kondisi yang dirasa sulit, individu dapat menemukan cara efektif untuk keluar dari masalah, merasa dirinya dihargai dan dicintai yang akan meningkatkan kepercayaan pada dirinya untuk mampu menjalani kehidupan dengan lebih baik. Akan tetapi ketika individu tidak 
melihat bantuan sebagai bentuk dukungan, dan dukungan yang diberikan tidak sesuai, maka kecil kemungkinan individu dapat mengurangi stres. Lingkungan sosial di sekolah yang nyaman, dinamis, dan saling menghormati akan mendorong peserta didik untuk saling memberikan dukungan sosial. Secara tidak langsung hal tersebut dapat memupuk resiliensi didalam diri peserta didik. Resiliensi merupakan faktor penting dalam kehidupan, ketika perubahan dan tekanan hidup berlangsung begitu intens dan cepat, maka individu perlu mengembangkan kemampuan dirinya sedemikian rupa untuk mampu melewatinya secara efektif, mampu menjaga kesinambungan hidup yang optimal.

Sikap resiliensi yang sudah ada didalam diri peserta didik diharapkan dapat mengembangkan kemampuan komunikasi matematis. Dalam proses komunikasi matematis peserta didik pastinya pernah mengalami miss communication dalam mengkomunikasikan konsep-konsep matematika, berdampak peserta didik mengalami kegagalan dalam proses pembelajaran dan hilang semangat belajar peserta didik. Maka dari itu resiliensi matematis harus tertanam di dalam diri peserta didik. Agar peserta didik cepat bangkit dalam keterpurukan dan mengkondisikan situasi yang sulit menjadi hal yang wajar untuk dilalui. Sehingga dengan meningkatnya resiliensi matematis peserta didik dapat membuat komunikasi matematis peserta didik menjadi meningkat juga.

\section{SIMPULAN}

Berdasarkan pada hasil penelitian dapat disimpulkan bahwa terdapat pengaruh antara resiliensi matematis terhadap kemampuan komunikasi matematis. Oleh karena itu, hendaknya dalam kegiatan pembelajaran guru tidak berfokus pada pencapaian nilai akedemiknya saja, selain itu harus diperhatikan pula hal-hal yang dapat menarik perhatian peserta didik. Hal-hal yang dapat menumbuhkan kemampuan kognitif peserta didik, seperti menumbuhkan sikap resiliensi didalam diri peserta didik sehingga guru dapat lebih mudah mencapai tujuan pembelajaran. Salah satu tujuan tersebut adalah meningkatkan kemampuan komunikasi matematis peserta didik.

\section{UCAPAN TERIMA KASIH}

Dengan memanjatkan puji syukur kehadirat Allah SWT yang telah melimpahkan rahmat dan karunia-Nya kepada penulis sehingga akhirnya penulis dapat menyelesaikan artikel ini. Dalam proses penelitian ini tidak selalu berjalan dengan lancar. Penulis banyak menghadapi hambatan, namun adanya berbagai pihak yang memberikan bantuan, bimbingan dan dukungan. Oleh karena itu, penulis ingin menyampaikan rasa terimakasih kepada Dosen Universitas Indraprasta PGRI yang telah memberikan dukungannya sehingga penelitian ini berjalan dengan baik. Ucapan terimakasih juga diberikan kepada Ibu Umiarti, S.Pd., MM, selaku kepala sekolah SMP Insan Nur Muhammad Bogor, Ibu Dini Yantika selaku guru matematika dan seluruh peserta di kelas IX yang telah memberikan izin kepada kami untuk mengambil data dan melakukan penelitian di SMP Insan Nur Muhammad.

\section{DAFTAR RUJUKAN}

Arikunto, S. (2010). Prosedur Penelitian Suatu Pendekatan Praktik. Jakarta: Rineka Cipta.

Hasbullah, \& Wiratomo, Y. (2015). Metode, Model dan Pengembangan Model Pembelajaran Matematika. Jakarta: Unindra Press.

Hendriana, H. Rochaeti, E.E. Sumarmo, U. (2017). Hard Skills dan Soft Skills Matematik Siswa. Bandung: Refika Aditama.

Husna, M., \& Fatimah, S. (2013). Peningkatan kemampuan pemecahan masalah dan Komunikasi matematis siswa Sekolah Menengah Pertama melalui model pembelajaran kooperatif tipe Think-Pair-Share (TPS). Jurnal Peluang, 1(2), 81-92

Iman, S. A., \& Firmansyah, D. (2020). Pengaruh kemampuan resiliensi matematis terhadap hasil belajar matematika. Prosiding Sesiomadika, 2(1b). 
Johnston-Wilder, S. \& Lee, C. (2010a). Mathematical Resilience. Mathematics Teaching, 218, 38-41.

Kurnia, H. I., Royani, Y., Hendriana, H., \& Nurfauziah, P. (2018). Analisis kemampuan komunikasi matematik siswa smp di tinjau dari resiliensi matematik. JPMI (Jurnal Pembelajaran Matematika Inovatif), 1(5), 933-940.

NCTM. (2000). Principles and Standards for School Mathematics. Reston. Retrieved from va: Authur. Diakses pada tanggal 20 Juli 2020 pukul 14:15 WIB, http://educare.e-fkipunla.net.

OECD (2018). Programme for International Student Assessment (PISA). Diakses pada tanggal 09 Maret 2020 pukul 23:21 WIB, https://edukasi.kompas.com/read/2019/12/04/13002801/skor-pisaterbaru-indonesia-ini-5-pr-besar-pendidikan-pada-era-nadiem-makarim?page=all.

Sarafino, E. P., \& Smith. (2011). Health psychology: Biopsychosocial interactions (7th ed.). New Jersey: Jhon Willey \& Sons.

Shindy, S., \& Nurfitriyanti, M. (2020). Pengaruh Communication Skill dan Character Building terhadap Kemampuan Literasi Matematika. Diskusi Panel Nasional Pendidikan Matematika.

Sugiyono. (2017). Metode Penelitian Kuantitatif, Kualitatif, dan R\&D. Bandung: Alfabeta.

Supardi. (2013). Aplikasi Statistika dalam Penelitian Konsep Statistika yang lebih Komprehensif. Jakarta: Change Publication. 
166 Suparni, Nurfitriyanti, \& Eva 